\title{
Sediment characteristics of a thermokarst lagoon in the northeastern Siberian Arctic (Ivashkina Lagoon, Bykovsky Peninsula)
}

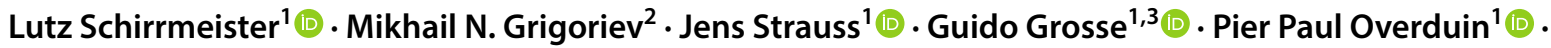 \\ Aleksander Kholodov $^{4} \cdot$ Frank Guenther ${ }^{1}\left[\right.$ [ $\cdot$ Hans-Wolfgang Hubberten ${ }^{1}$
}

Received: 22 August 2017 / Accepted: 18 May 2018

(c) Springer-Verlag GmbH Germany, part of Springer Nature 2018

\begin{abstract}
Lagoon development in ice-rich permafrost environments such as the Alaskan Beaufort Sea coastline and the Yedoma coastlines of northern Siberia represents a key mechanism of marine inundation of permafrost along the Arctic coastal plains. Here we show lithological, geochronological, and geochemical data from a core drilled in 1999 in Ivashkina Lagoon on the Bykovsky Peninsula in northeastern Siberia. This study extends previous studies of the Ivashkina Lagoon, and provides a first dated geochronological context for sedimentation and lithological characteristics. In addition, we report ground temperature measurements from different borehole sites in and around the lagoon to support our analysis of the thermokarst lagoon environment. Furthermore, a change detection study was carried out using historical aerial photography and modern satellite imagery for the 1982-2016 period. Several stages of landscape dynamics were reconstructed, starting with an initial Yedoma Ice Complex that covered the area during the late Pleistocene and which was locally thawed by thermokarst lake development during the Late Glacial with subsequent lacustrine sedimentation. A final stage completed the landscape dynamics during the last few hundreds of years. This stage was characterized by lake drainage and lagoon development, including strong reworking of surface sediments. By extrapolating the organic carbon data from Ivashkina Lagoon to the lagoons of the Bykovsky Peninsula, we estimate that lagoons contain 1.68 $\pm 0.04 \mathrm{Mt}$ of organic carbon in their upper $6 \mathrm{~m}$.
\end{abstract}

Keywords Permafrost region · Coastal dynamics · Paleoenvironment · Cryolithology $\cdot$ Geochronology $\cdot$ Hydrochemistry

\section{Introduction}

Thermokarst lagoons form when thermokarst lakes or drained thermokarst lake basins are flooded by ocean water. Thermo-erosional widening (including thermo-denudation and thermo-abrasion) of the former lake outlet channels

Lutz Schirrmeister

lutz.schirrmeister@awi.de

1 Department of Periglacial Research, Alfred Wegener Institute Helmholtz Center for Polar and Marine Research, Telegrafenberg A45, 14473 Potsdam, Germany

2 Mel'nikov Permafrost Institute, Siberian Branch of the Russian Academy of Sciences, Merzlotnaya St., 36, Yakutsk 677010, Russia

3 Institute of Earth and Environmental Science, University of Potsdam, Karl-Liebknecht-Str. 24-25, 14476 Potsdam, Germany

4 Geophysical Institute, University of Alaska Fairbanks, 903 Koyukuk Drive, Fairbanks, AK 99775, USA during the postglacial transgression and in the early Holocene transformed many thermokarst lakes along the Laptev Sea coast into lagoons [41]. Despite their importance as a transitional stage between freshwater and saltwater environments, and for coastal dynamics in Arctic permafrost regions, thermokarst lagoons and their depositional settings have rarely been investigated. Lagoon sediments undergo a complex series of multiple subaerial and subaquatic stages, in fresh, brackish and saltwater environments, resulting in both frozen and unfrozen layers that originate from former permafrost deposits that thawed in situ, from lacustrine sediments, or from marine sediments. This is typical for Holocene and modern coastal dynamics in most areas of the Arctic that are characterized by ice-rich permafrost [34]. Thermokarst lagoons provide interesting and often complex settings for biogeochemical and hydrochemical processes associated with subaquatic permafrost degradation under both freshwater and saltwater conditions. These processes and the different mechanisms of permafrost degradation (thermokarst, salt water intrusion, and tidal processes) 
distinguish lagoons as a natural experiment of permafrost degradation and a potential analogue for the impact of future sea level rise on permafrost coasts.

The Bykovsky Peninsula near Tiksi has been the subject of geoscientific and permafrost-related research for more than 200 years. It is one of the oldest study sites for permafrost paleo-environmental archives. Michael Adams made the first scientific description of a mammoth cadaver found in frozen sediments on the eastern coast of Bykovsky Peninsula in 1796 [1]. During the first International Polar Year (1881-1884), Alexander Bunge conducted research excursions to the icy permafrost coast of Bykovsky Peninsula from the Russian polar station at Sagastyr Island in the Lena Delta [6]. The Bykovsky Peninsula was also an important location for Soviet and subsequently Russian permafrost research at the turn of the last century [13, 24, 25, $28,51-53,57]$ and became a site of interest for a range of international studies [11, 30]. Since 1998 intensive paleoenvironmental studies have been conducted in the framework of the Russian-German science cooperation program System Laptev Sea. These studies focused mostly on the eastern coast of the Bykovksy Peninsula $[2,4,16,17,27$, $44,45,49,50,66]$. During this program, in the spring of 1999, a sediment core was drilled in Ivashkina Lagoon. In the spring of 2004, a second core was drilled by a Russian expedition to Ivashkina Lagoon. Their results on grain size, mineral composition, and sediment thermophysical properties were published by Cheverev et al. [7]. They showed that lake and lagoon deposits of about $1 \mathrm{~m}$ thickness consist of fine to coarse silty loam and clayish silt. Below, taberal deposits of thawed Ice Complex consist of silty to sandy loam. The lowest part of a $15 \mathrm{~m}$ core consists of coarse- to fine-grained alluvial sand. Later, within the framework of Russian-American expeditions in 2013 and 2014, the 39 and $38 \mathrm{~m}$ long cores 5D-13 and 1D-14 were drilled in the center and at the northern rim of Ivashkina Lagoon, respectively $[60,61]$. The boundary of ice-bonded permafrost was encountered at $12 \mathrm{~m}$ depth in both cores. The deposits are characterized by a high wood remnant content, well-defined stratification and gradational sediment textures. Sand beds contain dispersed rounded gravel-pebble material. Among the well-sorted sandy-alluvial formations are sandy layers with no signs of primary stratification. These formations are characterized by a high proportion of the sandy fraction (>90\%) and a high degree of sorting. Ulyantsev et al. [59] studied the organic and inorganic carbon and total nitrogen (TN) values as well as the total organic carbon (TOC)/TN ratios of core 1D-14. The ionic composition of dissolvable material of the same core using water extracts was studied by Ulyantsev et al. [62]. In addition, biomarker studies were performed by Ulyantsev et al. [58], Drozdova et al. [9] and Romankevich et al. [38]. As references to subsea permafrost cores, Shakhova et al. [47] presented temperature curves and volumetric ice contents from both cores and Shakhova et al. [48] observed methane fluxes of $5-24 \mathrm{~g}^{-2} \mathrm{day}^{-1}$ in the Ivashkina Lagoon, which were emitted from 17 bubble seeps and recorded for $36 \mathrm{~h}$ using portable single-beam sonar and averaged over the total area of $3000 \mathrm{~m}^{2}$.

In this paper, we present data from the core drilled in 1999 combined with ground temperatures later measured around the lagoon. Our studies complement previous investigations of the Ivashkina Lagoon environment. While we also characterize the sediment with analyses of the grain size distribution, we additionally report mass-specific magnetic susceptibility (MS) and a range of biogeochemical sediment properties important for biogeochemical characterization of such lagoon sediments, including TOC, TN, TOC/TN, and stable OC isotope $\left(\delta^{13} \mathrm{C}\right)$. To better understand changes in the pore water of the depositional environment, sediment extractions were performed and analyzed $[\mathrm{pH}$, electrical conductivity (EC), major ions]. Finally, we report the first radiocarbon accelerator mass spectrometry (AMS) ages for the Ivashkina Lagoon, giving the lagoon dynamics a geochronological context. While in the former studies the upper sediment layers were characterized by only five to nine samples, our data provide higher resolution with about 80 samples for the upper $6 \mathrm{~m}$. With this study we aim to: (1) reconstruct the depositional and degradation history of Ivashkina Lagoon, and (2) estimate an organic matter (OM) inventory of the regional lagoons.

\section{Study area}

The region consists of two major geological components. The Bykovsky Peninsula hinterland is characterized by the Kharaulakh Range with heights up to $500 \mathrm{~m}$ above sea level (asl). These hills are part of the northern foothills of the Verkhoyansk Mountains. Farther east, in the foreland of the Kharaulakh Range, the Bykovsky Peninsula consists of the remains of a former sediment accumulation plain with elevations of up to $45 \mathrm{~m}$ asl. The stratigraphic map of Sergienko et al. [46] distinguishes two structural regions: The "Kharaulakhsky Rayon" with a general uplift tendency during the Pleistocene and Holocene, and the "Buorkhainsky Rayon" (including the Bykovsky Peninsula) with a general subsidence tendency. Intensive vertical block tectonics and strong seismic activity along a listric fault system on the western coast of Buor Khaya Bay characterize this terrain due to its position at the western margin of the Ust-Lena Rift $[8,13$, 21]. The position of the Bykovsky Peninsula in a zone of subsidence likely explains the large thickness of the Yedoma Ice Complex in these locations [22] and the fact that the icerich terrestrial Yedoma deposits exposed at the coast extend down below current sea level [12, 28]. 
Modern Bykovsky Peninsula surface morphology consists of Yedoma hills (47\%), numerous thermokarst depressions $(46 \%)$ with lakes, and thermo-erosional valleys (6\%) $[16,17]$. The thermokarst landforms result mainly from early Holocene thermokarst and thermal erosion [17]. Ongoing thermo-erosion along the coast is constantly shaping the peninsula coastline and causing retrogressive thaw slumping along shores adjoining Yedoma uplands, leading to the development of thermo-terraces and exposed ice-rich cliffs $[14,29]$. Seven thermokarst lagoons covering an area of $10.862 \mathrm{~km}^{2}$ in total [16] in different stages of degradation are located along the southern coast of the peninsula (Fig. 1) and some very low-lying thermokarst basins along the eastern coast are affected by periodic marine ingressions [39-41].

The mean annual ground temperature (MAGT) at the depth of zero seasonal amplitude, about $20 \mathrm{~m}$ in this region, is $-10{ }^{\circ} \mathrm{C}$ in the Yedoma hills [12] and $-9{ }^{\circ} \mathrm{C}$ within drained thermokarst lake basins [42]. The slightly warmer temperature regime within alases is most likely the result of deeper snow there than on windblown uplands. Continuous ground temperature measurements indicate that permafrost temperature in this area has been gradually increasing at a rate of about $0.1{ }^{\circ} \mathrm{C}$ per year since 2007 [26], a typical rate of increase for cold permafrost around the circum-Arctic [42].

\section{Methods}

\section{Field work}

The coring was done with a UKB-12/25-01 Russian rotary drill rig on May 22, 1999 at the Iv-99 site (Fig. 1) at the center of Ivashkina Lagoon $\left(71.744^{\circ} \mathrm{N}, 129.401^{\circ} \mathrm{E}\right)$. A total drilling depth of $8.7 \mathrm{~m}$ below the ice surface $(6.2 \mathrm{~m}$ below the lagoon bed) was achieved. The core segments were stored in plastic liners and transported to Germany. The icebonded permafrost table was not reached. To probe deeper, a metal rod (3 $\mathrm{cm}$ in diameter) was hammered as deeply as possible into the sediment at the bottom of the borehole. One day later the borehole temperature was measured using a thermistor chain (MT-4) and a DC bridge down to $7.5 \mathrm{~m}$ below the ice surface.

Temperature was also measured in five boreholes close to the lagoon in 2003 and 2004 (Fig. 1). A 26 m deep borehole (BY 1) drilled in 2003 is located on the top of
A

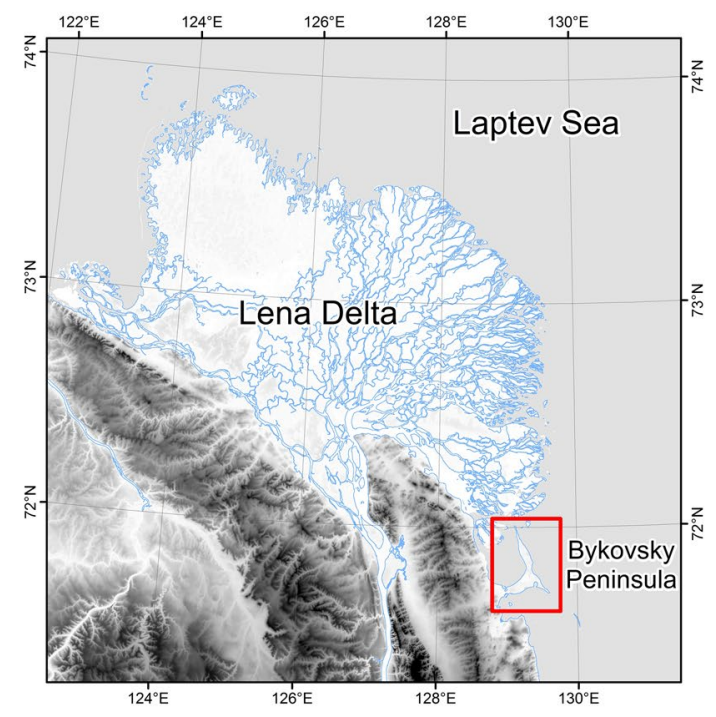

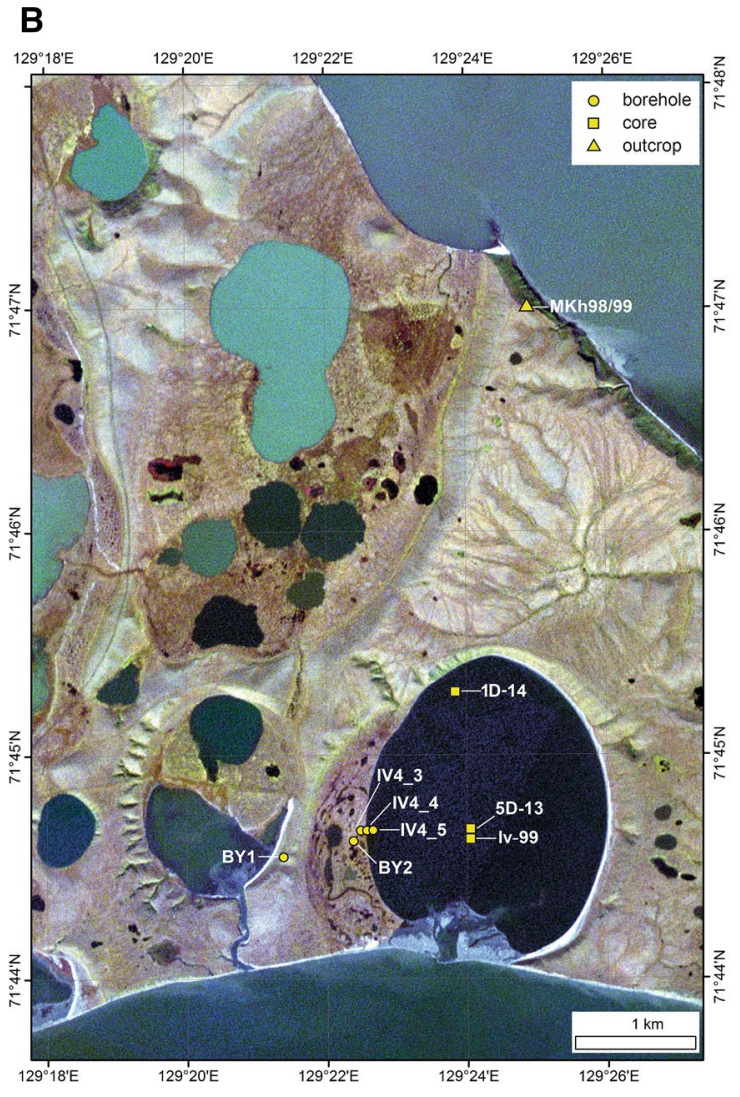

Fig. 1 Ivashkina Lagoon study area. a Position of the Bykovsky Peninsula southwest of the Lena Delta. b Positions of the boreholes and exposures mentioned in the paper (background image RapidEye 2014) 
the Yedoma ridge between Ivashkina Lagoon and the Polar Fox Lagoon basin. Four more boreholes were located at the western edge of the Ivashkina Lagoon depression. The $13 \mathrm{~m}$ deep BY-2 borehole was drilled in 2003. Three more boreholes were drilled in 2004. Borehole IV4-3 was located about $10 \mathrm{~m}$ from shore (14 m deep). Borehole IV4-4 was located close to the lagoon shoreline (4 m deep) and borehole IV4-5 was about $20 \mathrm{~m}$ offshore ( $9.5 \mathrm{~m}$ deep). In 2003-2006 we made single measurements at the landbased boreholes using a thermistor string with an accuracy of $\pm 0.1{ }^{\circ} \mathrm{C}$. In 2007 the BY-1 Yedoma ridge borehole and the IV4-3 offshore borehole were instrumented for continuous measurements with a 4-channel HOBO U12 data logger and TMC-HD thermistors with an accuracy of $\pm 0.02{ }^{\circ} \mathrm{C}$. Borehole IV4-3 logged temperature data between 2004 and 2009, borehole BY-2 from 2004 to 2006 and boreholes IV4-4 and IV4-5 in April 2004.

\section{Remote sensing}

Change detection for analyses of thermo-erosional widening and thus potential lagoon sediment supply magnitudes was carried out using historical aerial photography and modern satellite imagery. Based on a WorldView-2 stereo digital elevation model (DEM) from 2015, we ortho-rectified the most recent WorldView-3 image (02 Sept 2016) at a spatial resolution of $30 \mathrm{~cm}$, which in turn provided the reference frame for precise aerotriangulation (RMSE $1.18 \mathrm{~m}$ ) of two 1982 air photos and resampling at $0.7 \mathrm{~m}$ pixel size. The lagoon shoreline was mapped in both datasets and changes were measured along transects with an equidistance of $10 \mathrm{~m}$.

\section{Dating}

Radiocarbon dating was performed on seven samples from the sediment core using AMS at the Cologne AMS Laboratory, Germany, using a 6 MV Tandetron. Samples were prepared using standard methods, including acid-alkali-acid (AAA) extraction with $1 \% \mathrm{HCl}$ and $1 \% \mathrm{NaOH}$. Extraction times with $\mathrm{HCl}$ and $\mathrm{NaOH}$ were reduced if the plant fragments were small and fragile to avoid sample destruction or loss. The clean and dry samples were combusted and the $\mathrm{CO}_{2}$ was converted into graphite [37]. Conventional radiocarbon ages were calculated following the conventions defined by Stuiver and Polach [56]. Samples were corrected for carbon contributions from exogenous sources using sizematched, radiocarbon-free material (coal), which was processed similar to the samples. Ages were calibrated using the OxCal v. 4.2.4 software [5] and the IntCal13 calibration curve [35].

\section{Laboratory analyses}

Sediments were freeze-dried, homogenized, and split into sub-samples for further analyses. Grain size analyses were carried out using a Malvern Mastersizer 3000 after removing OM with hydrogen peroxide (3\%). The grain size classification was based on Reineck and Sing [36] and Wenthworth [64]. Grain size data were evaluated using the Gradistat v8 software [3]. The total elemental carbon (TC) and TN contents were measured with a VARIO-EL-III Element Analyzer, while TOC content was measured with the VARIO MAX C. These data were used to characterize basic OM quantity and quality parameters. Using the TOC and TN values, the TOC/TN ratio $(\mathrm{C} / \mathrm{N})$ was calculated to deduce the degree of OM decomposition. For TOC and $\delta^{13} \mathrm{C}$ analyses, samples were decalcified for $3 \mathrm{~h}$ at $95{ }^{\circ} \mathrm{C}$ by adding $1.3 \mathrm{~N} \mathrm{HCl}$. Total inorganic carbon (TIC) content was calculated by subtracting TOC from TC. The $\delta^{13} \mathrm{C}$ of TOC was measured with a Finnigan DELTA $S$ mass spectrometer and is expressed in delta per mil $(\delta \%)$ notation relative to the Vienna Pee Dee Belemnite (VPDB) standard with an uncertainty of $0.15 \%$. The variations in $\delta^{13} \mathrm{C}$ indicate changes in the local vegetation and the decomposition degree of OM [20]. Mass-specific MS indicating the content of magnetic and magnetizable minerals was measured after sample drying, homogenization, and splitting using a Bartington MS2 instrument equipped with the MS2B sensor. The data are expressed in SI units $\left(10^{-8} \mathrm{~m}^{3} \mathrm{~kg}^{-1}\right)$.

To get information about dissolvable material characteristics from the dry samples, the water-soluble elements in the core sediments were determined by shaking the samples with a proportionate amount of ultrapure water for a defined period of time. To obtain the water extracts, approximately $1 \mathrm{~g}$ of the freeze-dried sample was shaken for approximately $90 \mathrm{~min}$ in $50 \mathrm{ml}$ centrifuge tubes with ultrapure water at a soil:water ratio of 1:25 using an overhead shaker (Gerhardt Laboshake). Then, the suspension was centrifuged (Heraeus Multifuge $3 \mathrm{~s}$ ) at $4000 \mathrm{rpm}$ for $15 \mathrm{~min}$. The decanted extraction was filtered through a $0.45 \mu \mathrm{m}$ cellulose acetate filter. We measured total dissolved elemental concentrations of $\mathrm{Al}$, $\mathrm{Ba}, \mathrm{Ca}, \mathrm{Fe}, \mathrm{K}, \mathrm{Mg}, \mathrm{Mn}, \mathrm{Na}, \mathrm{P}, \mathrm{Si}$, and $\mathrm{Sr}$ and anion concentrations of $\mathrm{F}^{-}, \mathrm{Cl}^{-}, \mathrm{SO}_{4}{ }^{2-}, \mathrm{Br}^{-}, \mathrm{NO}_{3}{ }^{-}, \mathrm{PO}_{4}{ }^{3-}$, and $\mathrm{HCO}_{3}{ }^{-}$. Only values for $\mathrm{Ca}, \mathrm{K}, \mathrm{Mg}, \mathrm{Na}, \mathrm{Cl}^{-}, \mathrm{SO}_{4}{ }^{2-}$, and $\mathrm{HCO}_{3}{ }^{-}$are presented in this study. All other values either lay below the detection limit of the measurement or are not relevant for this study. The element concentrations were analyzed using inductively coupled plasma-optical emission spectrometry (ICP-OES, Perkin-Elmer Optima 8300DV), while the anion content was determined by ion chromatography (IC, Thermo ICS2100). Hydrogen carbonate concentrations were measured by potentiometric $\mathrm{pH}$ value titration with $0.01 \mathrm{M} \mathrm{HCl}$ using an automatic titrator (Metrohm 794 Basic Titrino). To estimate the procedural error, extractions were carried out 
in duplicate for every 5th-10th sample and 2-3 blank solutions of ultrapure water were treated in the same manner as the extractions and measured for concentrations. Water EC and $\mathrm{pH}$ values were measured using a WTW MultiLab 540 multi-parameter device equipped with a TetraCon 325 cell referenced to $25^{\circ} \mathrm{C}$ and a pH Sentix 81 electrode.

\section{Statistical methods for carbon inventory upscaling}

Our first order lagoon carbon stock calculation is based on bootstrapping techniques using resampled observed values. Following the approach introduced by Strauss et al. [54], we adjusted the approach in several ways. The number of resampling steps for each parameter was connected to the original number of observations of the TOC and bulk density parameters. For bulk density calculation, we used the approach for saturated sediments by Strauss et al. [54]. Water content was set to $30 \%$ for the core to infer bulk density. For the thickness we used the maximum core sample depth of $6.15 \mathrm{~m}$. For the areal extent we follow Grosse et al. [16] in using $10.862 \mathrm{~km}^{2}$. We did 10,000 separate bootstrapping runs and the total mean carbon stock size estimate was derived afterward for every bootstrapping run. This resulted in an overall mean value calculated from 10,000 observationbased bootstrapping means. Because TOC and bulk density of individual sediment samples are correlated, paired values were used in the resampling process. Computations were performed using R software (boot package).

\section{Results}

\section{Visual core stratigraphy}

According to the visual description of sediment recovered from borehole Iv-99 during the field expedition in May 1999 done by M.N. Grigoriev, the examined profile consisted of lagoon ice (0.0-2.2 $\mathrm{m})$ above salty water $(2.2-2.5 \mathrm{~m})$, below which the sediment sequence was described (Table 1).
The metal rod hammered further into the borehole encountered harder and likely slightly frozen ground at a depth of $16 \mathrm{~m}$ from the surface of the ice cover and finally did not penetrate further beyond a depth of $16.15 \mathrm{~m}$. This depth was interpreted as the top of fully frozen ground.

\section{Ground temperature measurements}

Borehole temperatures were measured the day after the drilling was completed and provide general information about temperatures and gradients below the lagoon bed in spring (Table 2).

For comparison, the ground temperature in April 2004 west of the lagoon itself was $-8.8^{\circ} \mathrm{C}$ at $14 \mathrm{~m}$ depth within the drained part of the Ivashkina Lagoon depression (IV4-3, about $10 \mathrm{~m}$ from the shoreline) and $-9.8{ }^{\circ} \mathrm{C}$ at the edge of the depression (BY-2, about $150 \mathrm{~m}$ from the shore). Sediment temperatures $4 \mathrm{~m}$ below the lagoon bed were $-8.6^{\circ} \mathrm{C}$ (IV4-4, shoreline) and $-5.5^{\circ} \mathrm{C}$ (IV4-5, $20 \mathrm{~m}$ from shore; Fig. 2a). Based on the temperature profile obtained from a single measurement, MAGT at $10 \mathrm{~m}$ depth below the lagoon bottom could be estimated as about $-4 \pm 0.5^{\circ} \mathrm{C}$. Based on these temperature observations, subaquatic permafrost is present below the lagoon bed from the shoreline out to at least $50 \mathrm{~m}$ from the shoreline. There are no boreholes close to the northern and eastern parts of the lagoon, where it is

Table 2 Temperature measurement in the Iv-99 borehole on 23 May 1999

\begin{tabular}{ll}
\hline Depth $(\mathrm{m})$ & $T\left({ }^{\circ} \mathrm{C}\right)$ \\
\hline 0 & -7.6 \\
0.5 & -7.4 \\
1.5 & -2.2 \\
2.5 & -1.95 \\
3.5 & -1.85 \\
4.5 & -1.3 \\
5.5 & -0.7 \\
6.5 & -0.3 \\
7.5 & 0.1 \\
\hline
\end{tabular}

Table 1 Field description of the material from the Iv-99 borehole

\begin{tabular}{|c|c|c|}
\hline Below ice $(m)$ & $\begin{array}{l}\text { Core depth }(\mathrm{m}) \text {, } \\
\text { below the lagoon } \\
\text { bottom }\end{array}$ & Lithological description \\
\hline $0.0-2.2$ & & Lagoon ice \\
\hline $2.2-2.5$ & & Salty water \\
\hline $2.5-3.5$ & $0.0-1.0$ & $\begin{array}{l}\text { Dense dark (almost black) lagoonal fine-grained silt with admixtures of silty sand as well as plant } \\
\text { residues, water-saturated at the top }\end{array}$ \\
\hline $3.5-5.9$ & $1.0-3.4$ & Loam with fine-grained sand detritus \\
\hline $5.9-6.4$ & $3.4-3.9$ & Fine-grained sand and silt with peaty interlayers and wood \\
\hline $6.4-8.7$ & $3.9-6.2$ & $\begin{array}{l}\text { Fine-grained to medium-grained sand with interlayers of silt and fine-grained gravel, rare inclusions of } \\
\text { shell residues }\end{array}$ \\
\hline
\end{tabular}




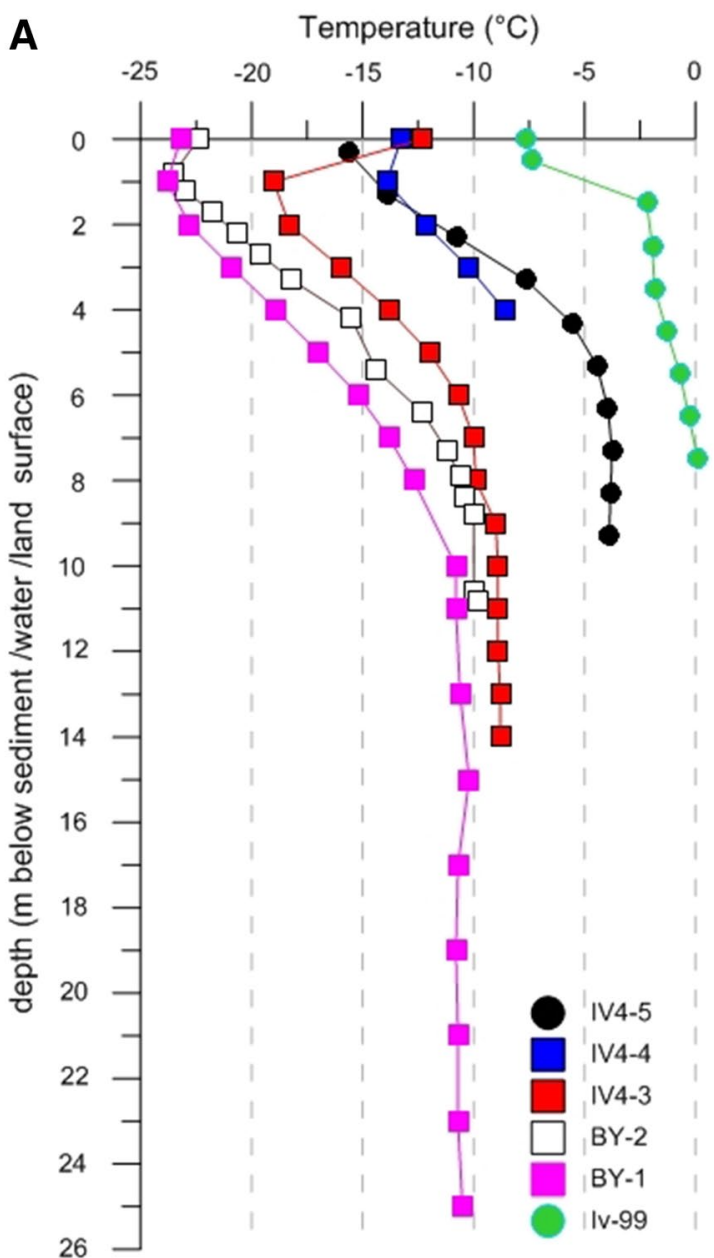

Fig. 2 Profiles of borehole temperature measurements. a Temperatures measured in April 2004, offshore: about $20 \mathrm{~m}$ from shore (IV45) and at the shoreline (IV4-4); and onshore: $10 \mathrm{~m}$ from shore (IV43), about $150 \mathrm{~m}$ from shore (BY-2, at the alas edge), and $250 \mathrm{~m}$ from

bordered by Yedoma hills. The typical ground temperature onshore is about $-10^{\circ} \mathrm{C}$. Ground temperature increased by about $0.7^{\circ} \mathrm{C}$ between 2007 and 2016 (Fig. 2b).

\section{Remote sensing}

Measurements of thermo-erosional widening over the 1982-2016 period revealed a mean annual lagoon expansion rate of $0.36 \pm 12 \mathrm{~m} \mathrm{a}^{-1}$, which corresponds to a mean absolute distance of $12.1 \pm 4.2 \mathrm{~m}$ over these 34 years. Changes have been observed almost exclusively along the western shoreline of the lagoon (Fig. 3a), while the eastern shoreline exhibits no changes, except for pronounced beach dynamics associated with water level fluctuations within the lagoon. Generally, the eastern shore of Ivashkina Lagoon is protected by a belt of tightly packed driftwood up to $70 \mathrm{~m}$ wide, which prevents the adjacent Yedoma slopes from shoreline-induced

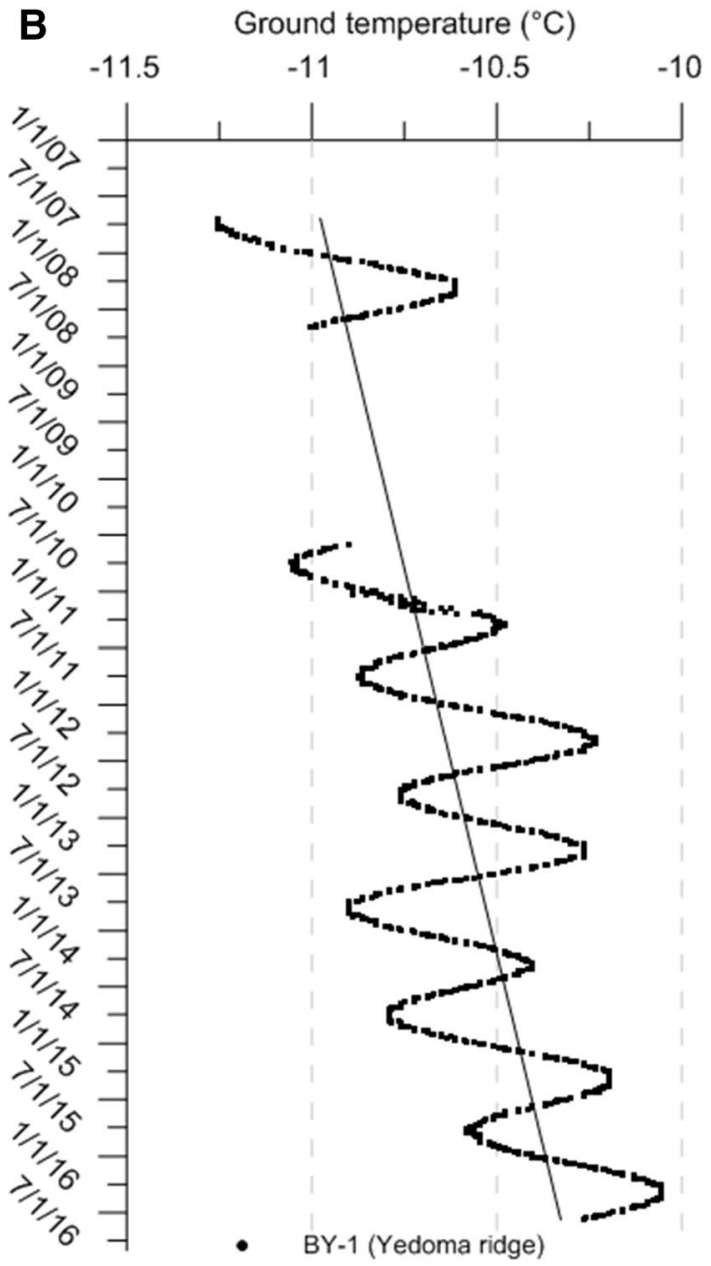

shore (BY-1, on the Yedoma hill). The borehole temperatures were measured at the lagoon center (Iv-99) on 23 May 1999 (squaresonshore, circles-offshore). b Ground temperatures at $15 \mathrm{~m}$ depth in the Yedoma ridge borehole between 2007 and 2016 (BY-1)

thaw slumping. Out of the $2730 \mathrm{~m}$ of erosive shoreline segments, $650 \mathrm{~m}$ are bordered by Yedoma slopes, $78 \%$ of which are affected by gentle thaw slumping and feature the slowest thermo-erosional lagoon widening of $0.15 \mathrm{~m}_{\text {year }}{ }^{-1}$. In contrast, along the drained part of the Ivashkina Lagoon depression that constitutes $76 \%$ of the erosive segments, rates were considerably higher at $0.4 \mathrm{~m} \mathrm{year}^{-1}$ on average (Fig. 3b). For comparison, the Tiksi Bay coastline adjacent to Ivashkina Lagoon generally experiences thermo-erosion rates ranging from 1.1 to $1.5 \mathrm{~m} \mathrm{year}^{-1}$.

\section{Geochronology}

Radiocarbon AMS dating of sediment from the upper approximately $2 \mathrm{~m}$ of the Iv-99 sediment profile are only several 100 years old (Table 3 ) and are very likely disturbed due to ice rafting and wave action. Deeper in the 

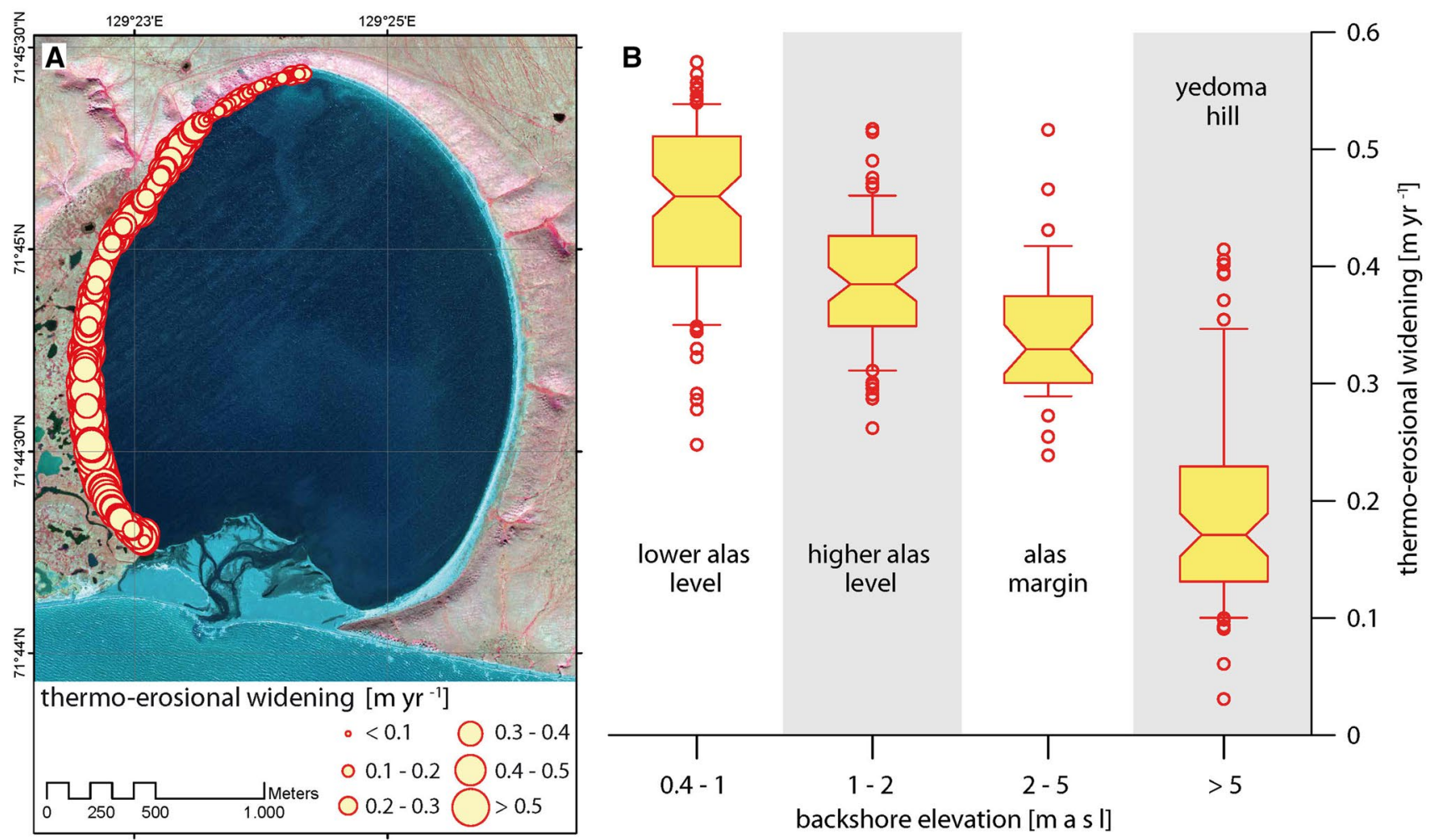

Fig. 3 Analyses of thermo-erosional widening of Ivashkina Lagoon. a Map showing location and thermo-erosion intensities around the lagoon shore. b Observations of thermo-erosion rates in relation to

classified elevation height ranges showing increased intensity at the low-lying thermokarst depression floor

Table 3 Results of the radiocarbon AMS dating

\begin{tabular}{lllcccc}
\hline AMS Lab ID & Sample ID & $\begin{array}{l}\text { Depth (m below the } \\
\text { lagoon bottom) }\end{array}$ & Age (year BP) & Age error \pm year & Age (years cal BP) & Sample material \\
\hline COL4390.1.1 & Iv2-99-08 & $0.44-0.46$ & 454 & 33 & $540-465$ & Wood fragments \\
COL4391.1.1 & Iv2-99-11/2 & $0.85-0.87$ & 452 & 33 & $539-465$ & Wood fragment \\
COL4392.1.1 & Iv2-99-15/2 & $1.90-1.92$ & 289 & 32 & $461-286$ & Wood fragment \\
COL4393.1.1 & Iv2-99-018 & $2.85-2.93$ & 20,992 & 85 & $25,586-25,101$ & Plant fragment \\
COL4394.1.1 & Iv2-99-023 & $3.99-4.03$ & 11,319 & 49 & $13,273-13,078$ & Plant fragment \\
COL4395.1.1 & Iv2-99-28 & $5.30-5.34$ & 24,212 & 100 & $28,564-27,941$ & Plant fragment \\
COL4396.1.1 & Iv2-99-36 & $6.08-6.11$ & 31,176 & 536 & $36,228-34,156$ & Bulk sediment \\
\hline
\end{tabular}

core the recovered sediment sequences were much older and were dated between 13.3 and 36.2 thousand years (calibrated) before present (kyrs cal BP). Ages were inverted between 2.9 and $4 \mathrm{~m}$ depth, where a date of $25.5 \mathrm{kyrs}$ cal $\mathrm{BP}$ at $2.9 \mathrm{~m}$ depth was followed by a younger age of 13.3 kyrs cal BP at $4 \mathrm{~m}$ depth. While the $13.3 \mathrm{kyrs}$ cal BP age possibly reflects the initial stage of the thermokarst lake formation, the older age above may be due to input of older reworked material from shore erosion. The lower two ages between 27.9 and 36.2 kyrs cal BP in correct geochronological order likely confirm the existence of a talik that is composed of thawed Yedoma Ice Complex deposits.

\section{Lithological and geochemical analyses}

Core recovery was $66 \%$. Several gaps exist in the lower part of the core, between 3 and 3.8, 4.2-5.2, and 5.6-5.9 m below the lagoon bottom (34\% in total). Based on the sediment data (Fig. 4), the core can be subdivided visually into 


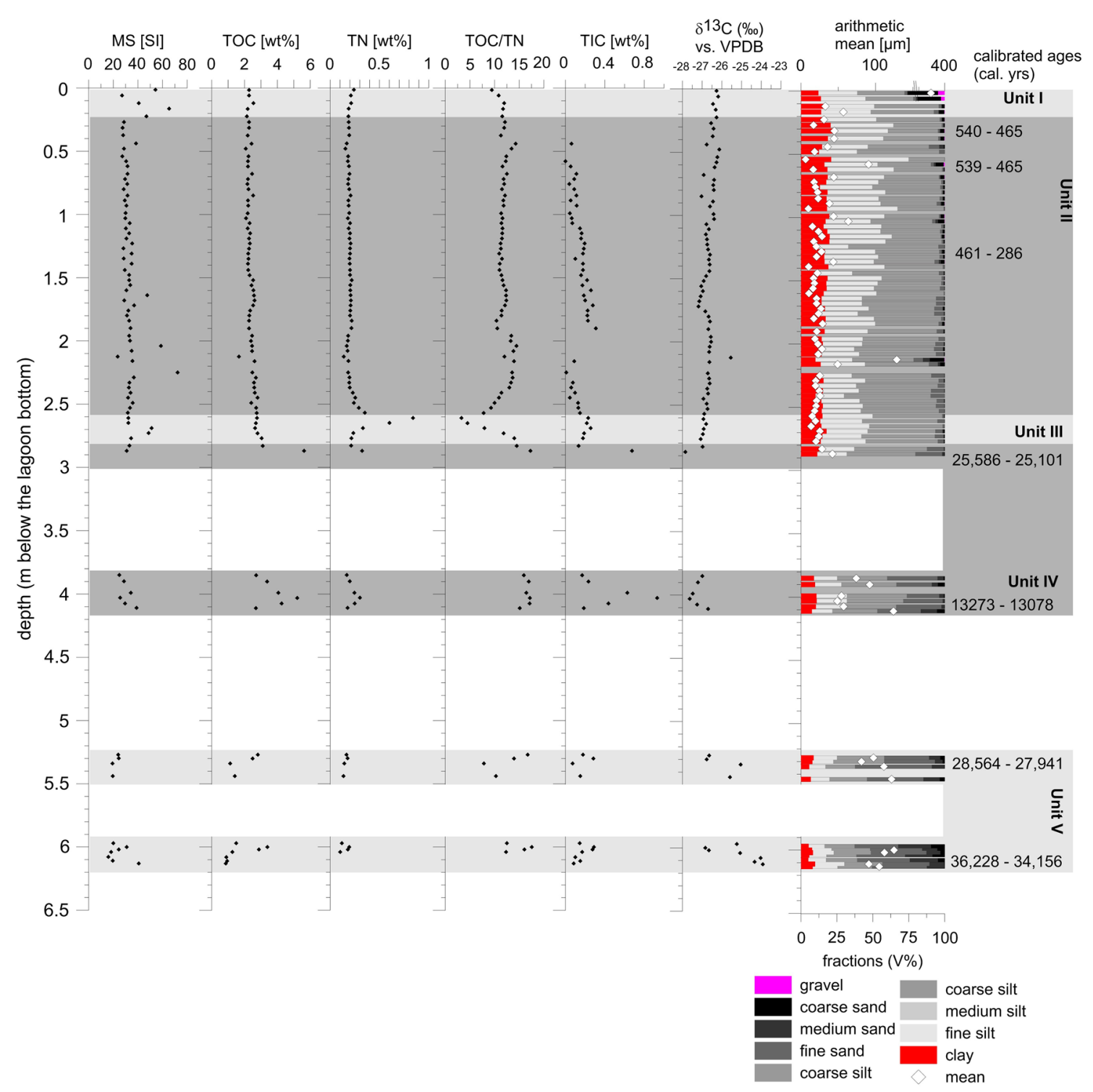

Fig. 4 Results of sedimentological analyses and age determination from the Iv-99 core

five different units. The uppermost Unit I (0.0-0.24 m) was characterized by high MS values (30-42.5 SI) and by higher sand and gravel contents, particularly in the upper two samples (grain size mean 255-374 $\mu \mathrm{m})$. Unit II $(0.24-2.51 \mathrm{~m})$ was characterized by relatively uniform sediment parameters; individual samples clearly had much higher MS values than in Unit I, between 47.7 and 72.3 SI. The next Unit III (2.51-2.85 m) was marked by an increasing TOC/TN ratio with depth; it reached high TOC (5.6 wt $\%$ ) and TIC (0.68 wt $\%)$ values, and a high TOC/TN ratio (17.3).

The sample with the smallest $\delta^{13} \mathrm{C}$ value in the sequence $(-27.8 \%$ at $2.93 \mathrm{~m})$ belongs to Unit IV. Following a sample gap from 3 to $3.8 \mathrm{~m}$, Unit IV $(2.93,3.8-4.15 \mathrm{~m})$ was characterized by strongly changing sediment parameters: MS ranged from 25 to 39 SI, TIC from 0.17 to $0.93 \mathrm{wt} \%$, and TOC from 2.9 to $5.2 \mathrm{wt} \%$. A fairly high TOC/TN ratio (15.1-17.2) marked relatively fresh $\mathrm{OM}$ in this unit. The $\delta^{13} \mathrm{C}$ values $(-27.6$ to $-26.6 \%$ ) fluctuated about $1 \%$ o within the $30 \mathrm{~cm}$ core segment. In addition, we note that the radiocarbon dating of $11319 \pm 49$ years BP was significantly younger than the sample age about $1.1 \mathrm{~m}$ higher up. Finally, Unit IV also had a higher sand content (grain size mean 49-124 $\mu \mathrm{m}$ ) than most of the samples above it. Below Unit IV, another gap in core recovery followed (4.2-5.2 m). The lowermost Unit V (5.27-6.15 $\mathrm{m})$ was characterized by a continuously high mean grain size $(81-192 \mu \mathrm{m})$, variable MS values (16.1-40.7 SI) and TOC/TN ratios (7.9-17.6), and the highest $\delta^{13} \mathrm{C}$ values in the core $(-26.8$ to $-23.9 \%$ ). A small gap in the recovered core existed within Unit V (5.6-5.9 m). 
If we calculate the OM inventory according to Strauss et al. [54] using calculated bulk density of water-saturated sediments, then the overall mean volumetric TOC content is $25 \pm 5 \mathrm{~kg} \mathrm{~m}^{-3}$. The upper part of the core down to $530 \mathrm{~cm}$ depth had $>20 \mathrm{~kg}$ TOC per $\mathrm{m}^{3}$. Similar to the gravimetric TOC, the highest volumetric TOC amount is present at $287 \mathrm{~cm}$, with a value of $39 \mathrm{~kg} \mathrm{~m}^{-3}$. In nearly all samples below $530 \mathrm{~cm}$, except for two samples around $600 \mathrm{~cm}$, TOC was less than $20 \mathrm{~kg}_{\text {per }} \mathrm{m}^{3}$ and reached its overall minimum of $10 \mathrm{~kg} \mathrm{~m}^{-3}$ at the deepest core sample $(615 \mathrm{~cm})$.

By applying a bootstrapping approach using carbon data of our Ivashkina Lagoon core and the peninsula's lagoon coverage of $10.862 \mathrm{~km}^{2}$ [16], we calculated the Bykovsky lagoon OM inventory to be as much as $1.68 \pm 0.04 \mathrm{Mt}$.

Based on analyses of sediment extractions, the EC was high in places; it changed between 728 and $2899 \mu \mathrm{S} \mathrm{cm}^{-1}$ in the uppermost part of the core, down to $0.44 \mathrm{~m}$ depth below the lagoon bottom (Fig. 5). The EC values deeper in the core were quite uniform (873-1349 $\mu \mathrm{S} \mathrm{cm} \mathrm{cm}^{-1}$ ). Beginning at $2.87 \mathrm{~m}$ depth the EC values decreased discontinuously from 2008 to $378 \mu \mathrm{S} \mathrm{cm}^{-1}$ at $6.13 \mathrm{~m}$ depth. In contrast, the $\mathrm{pH}$ value of the water extracts increased almost continuously from 5.1 near the lagoon bottom to 8.2 at the lower end of the sediment core. The highest EC values occurred in the uppermost core segment where the highest solute concentrations were observed. Aside from the uppermost core segment, concentrations in other parts of the core were characterized by either uniform or gradually decreasing values toward the lower end of the core.

As a reference, we used water extract data from a Yedoma Ice Complex exposure (Fig. 6) about $4 \mathrm{~km}$ north of the lagoon to compare degraded and non-degraded permafrost material. The EC values in the Yedoma sequence were more than one order of magnitude lower (15.7-263 $\mu \mathrm{S} \mathrm{cm}^{-1}$ ) than in the lagoon sequence and reflected freshwater conditions during sediment formation. The $\mathrm{pH}$ values of 5.6-7.8 varied over a similar range as in the Yedoma sequence. In keeping with the low EC, solute concentrations were quite low and reflected the freshwater depositional environment within the Yedoma sequence.

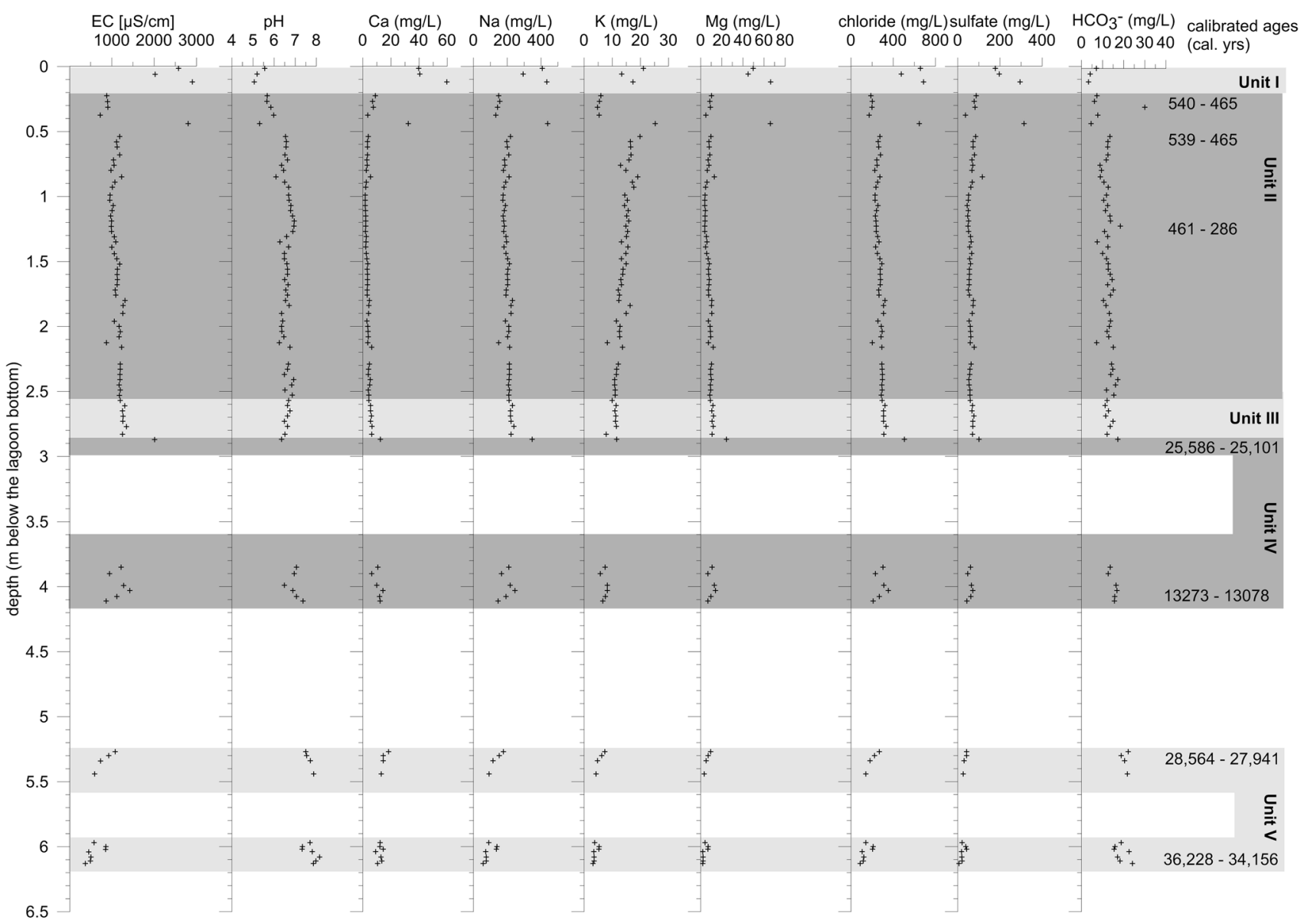

Fig. 5 Results of water extract analyses from the Iv99 Ivashkina Lagoon core 

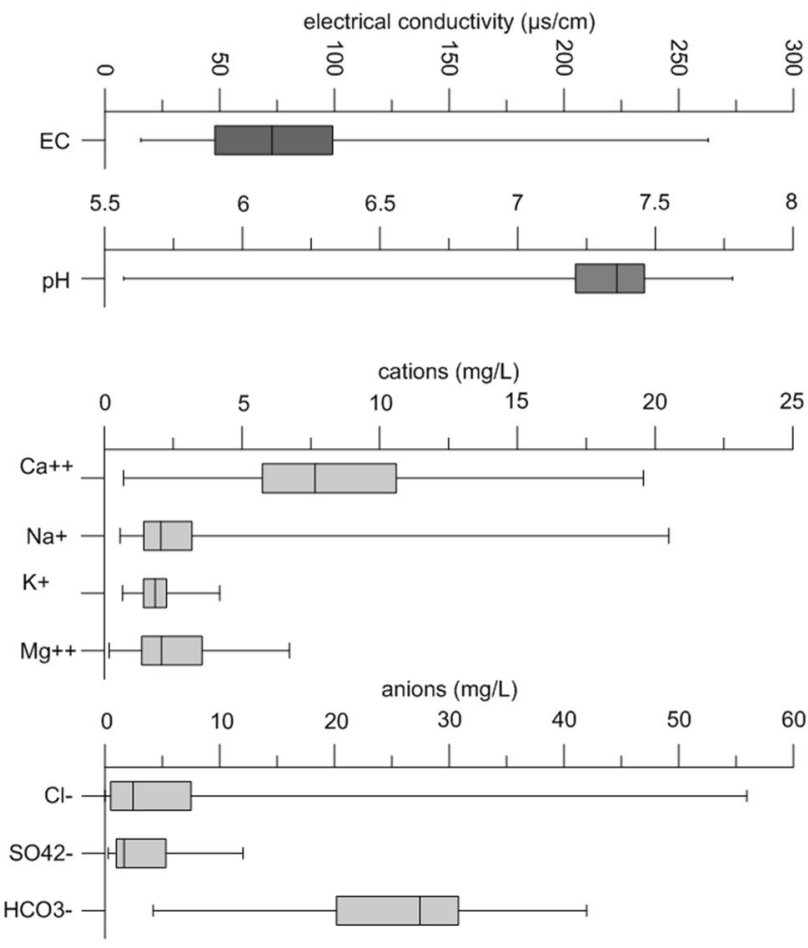

Fig. 6 Boxplot of water extract analyses from the Mamontovy Khayata Yedoma Ice Complex exposure at the east coast of the Bykovsky Peninsula $4 \mathrm{~km}$ north of Ivashkina Lagoon

\section{Discussion}

Although it is unlikely that thermal equilibrium had already been established in the borehole when the temperature was measured (23 May 1999), ground temperature measurements from the rim of Ivashkina Lagoon (Fig. 2a) demonstrate that permafrost is present around the lagoon. A significantly smaller warming trend from -1 to $0.5^{\circ} \mathrm{C}$ in the first meters was observed in 2013 in borehole 5D-13 [48]. Permafrost temperatures warmed by about $0.7^{\circ} \mathrm{C}$ between 2007 and 2016 at $15 \mathrm{~m}$ depth in the BY-1 borehole on the Yedoma ridge $250 \mathrm{~m}$ west of the lagoon (Fig. 2b), in line with general permafrost warming trends in northern Yakutia [42].

During drilling in 1999 no ice-bonded permafrost was recovered from the center of the lagoon in the deepest part of the Iv-99 borehole, $7.5 \mathrm{~m}$ below the ice surface. However, when the maximum drilling depth was extended by hammering in a metal rod, permafrost was likely reached at about $16 \mathrm{~m}$ depth below the lagoon ice surface $(13.5 \mathrm{~m}$ below the lagoon bottom).

Analyses of thermo-erosional widening around Ivashkina Lagoon revealed contrasting patterns of no change along the eastern shore and constant lagoon expansion along the western coast at a mean rate of $0.36 \mathrm{~m} \mathrm{year}^{-1}$. Although this rate is somewhat slower than the average erosion rate along the land-water interface of $0.59 \mathrm{~m}$ year $^{-1}$ for the entire
Bykovsky Peninsula, which can be attributed to the limited fetch for wave formation inside the lagoon, it is in accordance with the general pattern of slower coastal erosion rates along Yedoma coasts compared to higher rates along alas segments observed by Lantuit et al. [29]. Attributing our shoreline change observations to backshore height based on DEM data, we were able to differentiate between shoreline-height levels around the Ivashkina Lagoon depression (Fig. 3b). The effects of slow thermo-erosion rates along a Yedoma hill and considerably faster rates along alas segments not only comprise ground ice thaw and constant sediment supply from these two major geomorphological and sedimentological units, but also highlight the greater vulnerability of the low-lying drained part of the Ivashkina Lagoon depression to becoming inundated in the future. Regarding permafrost depths in areas close to the shore, Overduin et al. [32] suggests that the depth to ice-bonded permafrost close to shore is inclined steeply if the coastline retreat is slow and is inclined shallowly where rapid coastal erosion rates prevail. Although thermo-erosional widening within Ivashkina Lagoon generally proceeds at a slow rate, differences in the rate of widening may also be reflected in the subaquatic permafrost table depth.

According to sediment analyses, the Ivashkina core (Iv99) was subdivided into five units. The lowermost Unit V seems to be a thawed but not reworked part of the late Pleistocene Yedoma Ice Complex. Such sediments were studied in detail at exposures $4 \mathrm{~km}$ north of Ivashkina Lagoon (Fig. 1, [43-45, 50]). As shown in Fig. 7, the Yedoma Ice Complex at the Mamontovy Khayata site is characterized by coarser grain sizes, similar to the lowermost Unit V of the lagoon core. The next Unit IV is interpreted as the initial stage of thermokarst lake formation during the transition from the Late Glacial to the Holocene. According to Kaplina and Lozhkin [23] and Walter Anthony et al. [63], widespread thermokarst processes and lake formation in Siberia began at this time. Unit III includes the reworked material that was dated at $21 \pm 0.085 \mathrm{kyrs}$ BP. The samples above are characterized by a strong trend of OM degradation with a TOC/TN ratio from 17.3 to 3.3. Possibly, this gradient reflects a stage of thermokarst lake drainage during which aerobic soil conditions resulted in increased $\mathrm{OM}$ degradation at the surface. A modern analogue may be found in the several thermokarst lake basins along the modern shores of the Bykovsky Peninsula that lost their lakes due to drainage after the lake rims were breached by the sea. However, they have not yet transformed into lagoons because lake floors are still slightly higher than the mean sea level, which is in accordance with calculations of potential subsidence due to ground ice melt on nearby Muostakh Island [18].

At some point during the mid to late Holocene the Bykovsky Peninsula took on something close to its present form [17]. Marine ingression transformed a thermokarst lake 


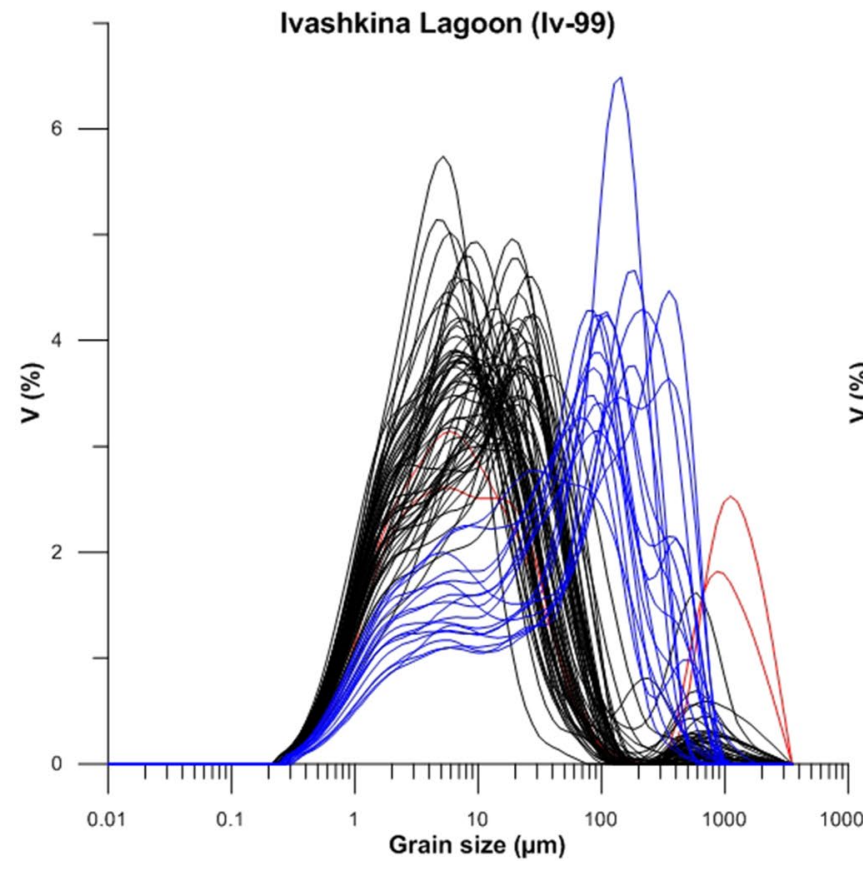

Fig. 7 Comparison of the grain size distribution curves from the Iv-99 Ivashkina Lagoon borehole (left panel) (red: coarse-grained samples from the uppermost layer; black: lagoon deposits; blue:

into Ivashkina Lagoon probably only during the last few 100 years. We observed driftwood deposited far from the coast in these former lake basins, indicating that episodic storm floods breached the basins, resulting in salinization of remnant lakes and soils. This salinization probably contributes to further ground ice thaw followed by subsidence that eventually allows full marine inundation. We may thus expect some sedimentary record of marine transgression such as an unconformity described by Forbes et al. [10], although marine influence has probably varied in intensity or been intermittent, depending on climatic shifts in sea ice and storm tracks. Tiksi Bay is connected to Ivashkina Lagoon through the lagoon opening. The surface water layer in Tiksi Bay is typically frozen as land-fast ice from late fall until June or July. In the summer months this layer can be strongly influenced by Lena River discharge flowing into Tiksi Bay between Cape Muostakh and Muostakh Island, which results in an earlier sea ice break-up and mean start of the open water season, currently around 21 July [18]. During high water events, for example storms, water from below the pycnocline can be forced up the beach and provide more saline water for the lagoon [65]. Most dissolved salts in the shallow water column are excluded from ice during fall and winter, resulting in brine formation being trapped below the ice within these basins [14]. A survey of late summer water conductivity in the lagoon showed a non-uniform distribution of salt, with ECs from 5800 to $6400 \mu \mathrm{S} \mathrm{cm}^{-1}$ and a clear trend of increasing values from the NW to the SE side

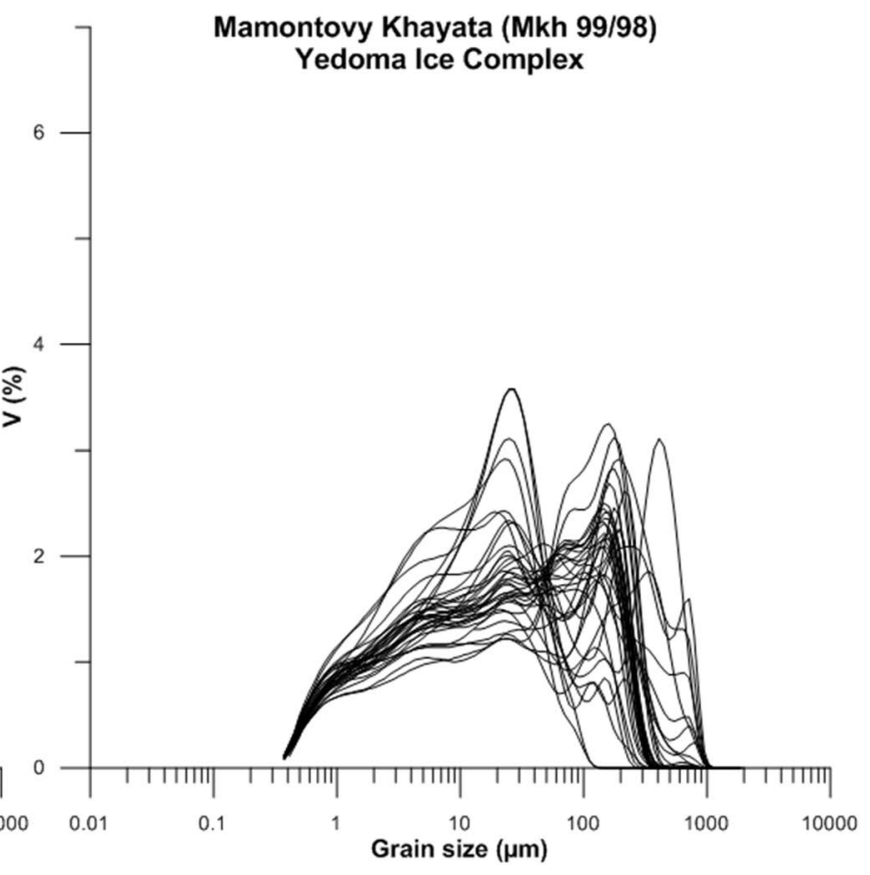

taberal deposits) and from the Yedoma Ice Complex at the Mamontovy Khayata site (right panel)

of the lagoon [33]. These values are higher by an order of magnitude than in adjacent thermokarst lakes. Our results show elevated values (over $2000 \mu \mathrm{S} \mathrm{cm}^{-1}$ ) only in the upper half meter of sediment, corresponding to the period following lake drainage (Units I and II), when a marine influence is probable. Deeper, down to $2.8 \mathrm{~m}$, the core shows relatively uniform EC values around $1000 \mu \mathrm{S} \mathrm{cm}^{-1}$, which could be explained by the downward transportation of salt solutions through the original freshwater sediment of a thermokarst lake. This kind of salt diffusion in thawed deposits has been described for subsea permafrost deposits by Harrison and Osterkamp [19], Gosink and Baker [15] and Osterkamp [31].

Unit II reflects the younger phase of the thermokarst lagoon, where sediments probably were disturbed by ice rafting and wave action in a shallow lagoon environment. The uppermost unit $I$ is characterized by a coarse-grained fraction in the uppermost samples, which could reflect shortlived higher-energy currents at the bottom of the lagoon.

There is a wide range in OM quantity and quality within the Iv-99 Ivashkina Lagoon core (Fig. 8). The TOC contents ranged between 0.9 and $5.6 \mathrm{wt} \%$ without a clear correlation with the core stratigraphy. The range of the TOC/CN ratio as a signal of the $\mathrm{OM}$ degradation is wide, between 3.3 (strongly degraded) and 17.6 (weakly degraded). The $\delta^{13} \mathrm{C}$ values, another signal of OM quality, are between -27.8 and $-23.9 \%$ and thus relatively heavy (less negative) with respect to the terrestrial OM quality within the core. The OM signal from the Yedoma Ice Complex at the Mamontovy 


\section{Ivashkina Lagoon (Iv 99)}
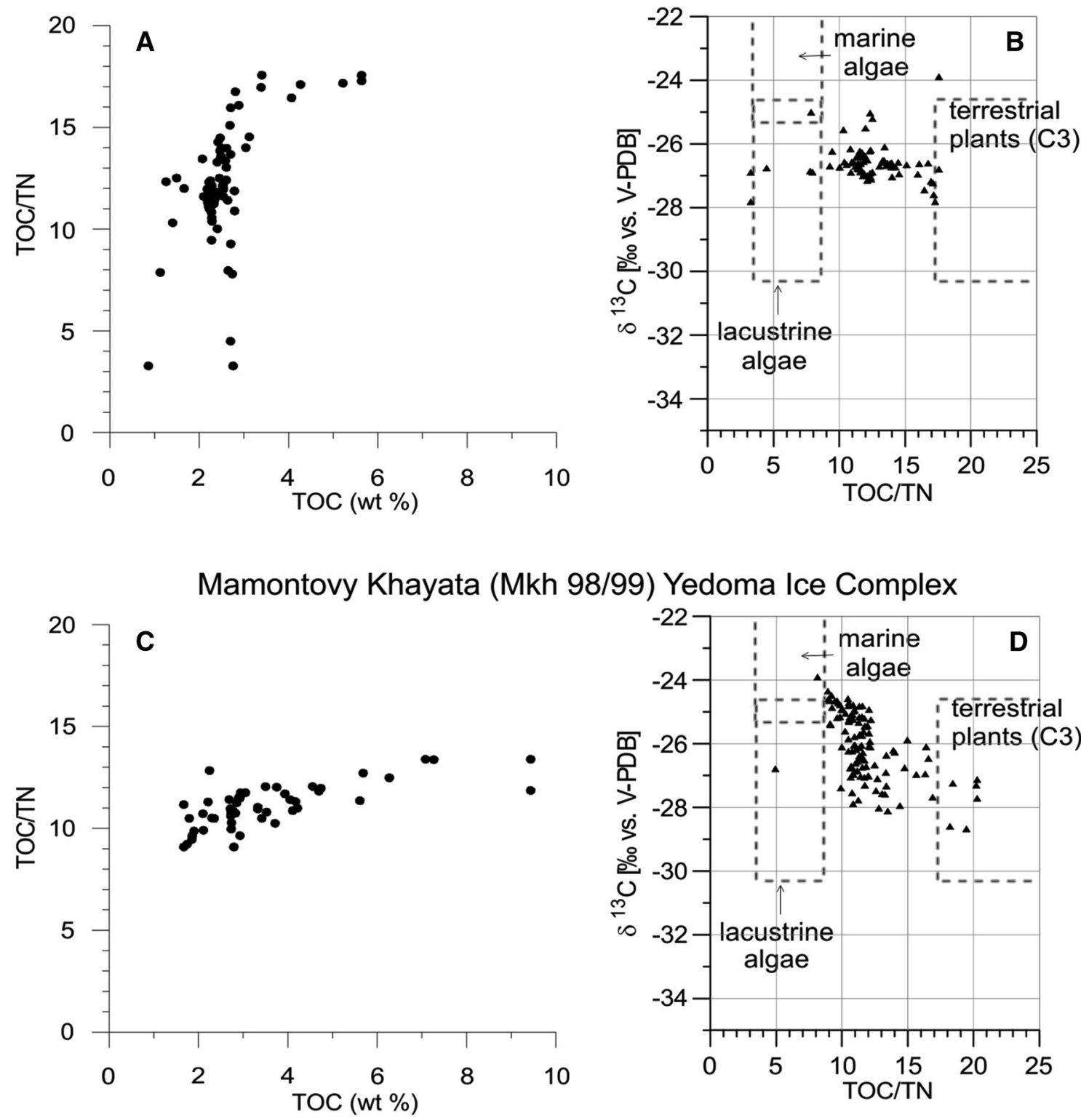

8/99) Yedoma Ice Complex

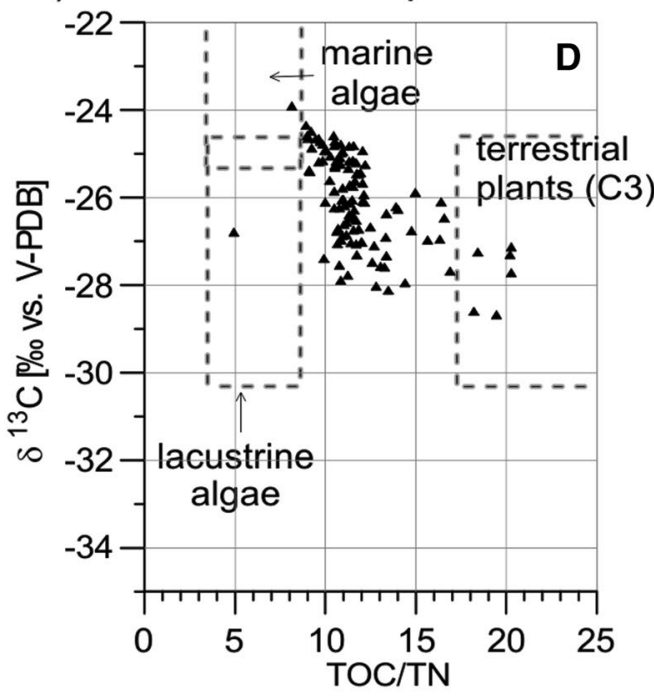

Fig. 8 OM quantity and quality in the Ivashkina Lagoon core (Iv-99) and the Yedoma Ice Complex exposure (Mkh 98/99) from the Bykovsky Peninsula

Khayata site shows a wider TOC range, between 1.7 and $13.8 \mathrm{wt} \%$, while the TOC/TN ratio is quite narrow, between 9.1 and 13.4, and the $\delta^{13} \mathrm{C}$ values are between -27.8 and $-24.5 \%$ (Fig. 8). When comparing the OM parameters of Unit $\mathrm{V}$ (taberal deposits) with the other core segments of Iv-99, the $\delta^{13} \mathrm{C}$ values are the heaviest between -25 and $-23.9 \%$. The TOC values of Unit $\mathrm{V}$ are often lower than $1.5 \mathrm{wt} \%$. Such values are in the lower or the lowest range of the nearby Yedoma Ice Complex deposit. This indicates carbon depletion in the talik taberal segment. The TOC/CN data of the taberal core segment are between 8 and 17.6 and thus in a similar range as the Yedoma deposits. Therefore, our methodological approach indicates that the OM in these few samples of drilled taberal sediments below Ivashkina Lagoon is modified due to permafrost thaw.

We here compare our data with other cores from the area, e.g., Cheverev et al. [7], as well as with data from Ulyantsev et al. [58-61], Romankevich et al. [38] and Drozdova et al. [9] for the 1D-14 and 5D-13 boreholes. In Cheverev et al. [7] the general stratigraphy with taberal, thermokarst lake, and lagoonal deposits is comparable. It is somewhat unfortunate that the position of the borehole and the depth of different layers are not reported. The deeper 1D-14 and 5D-13 cores are about $40 \mathrm{~m}$ long; the upper permafrost boundary 
is found at the $12 \mathrm{~m}$ depth. The core position of $1 \mathrm{D}-14$ is located at the northern rim of the lagoon. In this position the accumulation processes seem different than in the center, where Iv-99 was cored. The median grain size values of our core Iv-99 are clearly smaller compared to the nine values between ca. 200 and $400 \mu \mathrm{m}$ from the upper segment in core 1D-14 from Ulyantsev et al. [60] and Romakevich et al. [38]. The TOC/TN ratios have a wider variation as shown in the few data from the upper core segment of 1D-14 (TOC/ $\mathrm{CN}<$ ca. 10 ) by Ulyantsev et al. [58, 59]. Core 5D-13 is from the center of the lagoon. Only five TOC values of $<1$ to $<4 \%$ from the upper five meter segment are shown in Ulyantsev et al. [61].

Our studies on the Iv-99 core show different stages of landscape evolution. We assume that the Yedoma Ice Complex was the initial landscape stage covering the area during the late Pleistocene, similar to the Yedoma Ice Complex deposits which are still present at the nearby Mamontovy Khayata site. Following thermokarst lake development during the Late Glacial, a second stage is characterized by subaquatic permafrost thaw and taberite formation under freshwater lake conditions. Sediments in the core of this stage include thawed but not reworked Yedoma deposits which reflect the late Pleistocene age (28-36 cal kyrs BP) of these deposits, and potentially lacustrine sediments with ages of 13 kyrs cal BP and younger that contain reworked OM from eroding Yedoma shores. The thermokarst lake was drained and aerobic alas conditions should have existed, but they are not well-recorded in the Iv-99 sediment core. The final stage is represented by lake drainage and lagoon development, followed by strong reworking of surface sediments during the last few 100 years of the Holocene period.

Addressing the second aim of this study, estimating a first order OM inventory of the regional lagoons, we showed that the lagoon core includes $25 \pm 5 \mathrm{~kg} \mathrm{TOC} \mathrm{m}^{-3}$. This is in line with the $\mathrm{OC}$ values of the Yedoma domain [55]. If the wedge ice content is not taken into account in the volumetric carbon calculation, Strauss et al. [54] found a similar amount of OC for Yedoma deposits $\left(27 \mathrm{~kg} \mathrm{~m}^{-3}\right)$. In addition to the similar grain size distribution, these TOC values provide evidence for the connection between lagoon talik and Yedoma Ice Complex sediments. Applying a bootstrapping approach using carbon data of our Ivashkina Lagoon core and the Bykovsky Peninsula's lagoon coverage of $10.862 \mathrm{~km}^{2}$ [16] we were able to show that the studied first $6.15 \mathrm{~m}$ of the peninsula's lagoon sediments store about $1.68 \pm 0.04 \mathrm{Mt}$ of OC. As the taliks are deeper than assumed, this is a conservative estimate. At our coring site, we estimate that the talik is $13.65 \mathrm{~m}$ deep in the center of Ivashkina Lagoon, potentially doubling the estimate to about $3 \mathrm{Mt} \mathrm{OC}$ if TOC and bulk density are assumed to be constant. We suggest that this unfrozen OC in the lagoon's taliks functions as a perennially available source for microbial activity. Hence, such a substantial amount of unfrozen carbon promotes the production and release of methane and carbon dioxide, which is likely to increase in a warming Arctic.

\section{Conclusion}

Dynamic processes associated with thermokarst lagoon formation result in stratigraphically complex sediment cores that may reflect difficult chronologies due to the sediment re-deposition processes during stages of freshwater thermokarst and marine inundation. Moreover, sea ice formation and movement may disturb surface sediments in shallow lagoons. Accordingly, the chronology of such sediment archives may be challenging to interpret. Formation of taberal deposits in a talik below the Ivashkina Lagoon is reflected in the presence of thawed sediments with late Pleistocene sediment ages and sediment parameters that are similar to the deposits in Yedoma Ice Complex exposures located nearby. The OM in the few samples of drilled talik sediments below the lagoon differs in its characteristics from the Yedoma Ice Complex deposits, indicating partial decomposition associated with permafrost degradation. Different stages of landscape dynamics were reconstructed, starting with a late Pleistocene Yedoma Ice Complex covering the Bykovsky Peninsula area, followed by thermokarst lake development during the Late Glacial, a stage that is characterized by lake drainage and aerobic alas conditions, and finally lagoon development, including strong reworking of surface sediments during the last few 100 years of the Holocene period. Scaling carbon stocks of the Ivashkina Lagoon with total area of the lagoons of the Bykovsky Peninsula we estimate that these landscape units contain a perennially unfrozen carbon inventory of $1.68 \pm 0.04 \mathrm{Mt}$ OC for the top $6 \mathrm{~m}$ of sediments. This carbon pool may promote the production and release of methane and carbon dioxide, a process which is likely to increase in a warming Arctic with rising sea levels and enhanced permafrost degradation.

\section{Data availability}

Analytical data are available at https://doi.org/10.1594/ PANGAEA.878899.

Acknowledgements This work is part of the international RussianGerman drilling project Bykovsky Spring 2017. We gratefully acknowledge support for this study by the BMBF project CarboPerm, the ERC \#338335, and the Helmholtz Strategy and Networking Fund via ERC-0013. We thank Antje Eulenburg for help with hydrochemical lab work and Dyke Scheidemann for the sediment lab work. We also thank the team of Janet Rethemeyer from the Cologne AMS Laboratory. We thank Vladimir. E. Tumskoy from the Moscow State University for his support during field work in 1999. Finally, the paper benefited from English language corrections by Candace O'Connor 
(Fairbanks, Alaska) and the constructive comments of the two anonymous reviewers.

\section{References}

1. Adams M (1808) Some account of a journey to the frozen-sea, and of the discovery of the remains of a mammoth. Phila Med Phys J Part 1(3):120-137

2. Andreev AA, Schirrmeister L, Siegert C, Bobrov AA, Demske D, Seiffert M, Hubberten H-W (2002) Paleoenvironmental changes in Northeastern Siberia during the Late Quaternary-evidence from pollen records of the Bykovsky Peninsula. Polarforschung 70:13-25. https://doi.org/10.2312/polarforschung.70.13.

3. Blott SJ, Pye K (2001) Gradistat: a grain size distribution and statistics package for the analysis of unconsolidated sediments. Earth Surf Proc Land 26:1237-1248. https://doi.org/10.1002/esp.261

4. Bobrov AA, Andreev AA, Schirrmeister L, Siegert Ch (2004) Testate amoebae (Protozoa: Testacea) as bioindicators in the Late Quaternary deposits of the Bykovsky Peninsula, Laptev Sea, Russia. Palaeogeogr Palaeoclimatol Palaeoecol 209:165-181. https:// doi.org/10.1016/J.PALAEO.2004.02.012

5. Bronk Ramsey C, Scott EM, Plicht JVD, Reimer PJ (eds) (2013) Calibration for archaeological and environmental terrestrial samples in the time range 26-50 ka cal BP. Radiocarbon 55(4):20212027. https://doi.org/10.2458/azu_js_rc.55.16935

6. Bunge AA (1895) The Lena expedition 1881-1884. In: Tillo A (ed) Beobachtungen der russischen Polarstation an der Lenamündung. Expedition der Kaiserlichen Russischen Geographischen Gesellschaft, St. Petersburg, pp 1-96 (in German)

7. Cheverev VG, Vidyapin IYu, Tumskoy VE (2007) Composition and characteristics of the thermokarst lagoon deposits, Bykovsky Peninsula. Kriosfera Zemli 11(3):44-50 (in Russian)

8. Drachev SS, Savostin LA, Groshev VG, Bruni IE (1998) Structure and geology of the continental shelf of the Laptev Sea, Eastern Russian Arctic. Tectonophysics 298:357-393. https://doi. org/10.1016/S0040-1951(98)00159-0

9. Drozdova AN, Vetrov AA, Romankevich EA, Prokuda NA, Sukhoverkhov SV, Bratskaya SYu, Sergienko VI, Semiletov IP, Ulyantsev AS (2016) Polycyclic aromatic hydrocarbons in Holocene-Pleistocene sediments of the Laptev Sea. Dokl Earth Sci 468:496-499. https://doi.org/10.1134/S1028334X16050123

10. Forbes DL, Manson GK, Whalen DJR, Couture NJ, Hill PR (2015) Coastal products of marine transgression in cold-temperate and high-latitude coastal-plain settings: Gulf of St Lawrence and Beaufort Sea. In: Martini IP, Wanless HR (eds) Sedimentary coastal zones from high to low latitudes: similarities and differences, vol 388. Geological Society, London, Special Publications, London, pp 131. https://doi.org/10.1144/SP388.18

11. Fukuda M (1994) Occurrence of Ice-complex (Edoma) in Lena River Delta Region and Big Lhyakovsky Island, High Arctic Eastern Siberia. In: Inoue G (ed) Proc 2nd Symp on the joint Siberian Permafrost Studies between Japan and Russia, pp 5-13

12. Grigoriev MN (1993) Cryomorphogenesis of the Lena River mouth area. Yakutsk. SO AN SSSR, pp 1-176 (in Russian)

13. Grigoriev MN, Imaev VS, Koz'min BM, Kunitski VV, Larionov AG, Mikulenko KI, Skryabin RM, Timirshin KV (1996) Geology, seismicity and cryogenic processes in the arctic areas of western Yakutia. Scientific Center SD RAS, Yakutsk pp 1-80 (in Russian)

14. Grigoriev NF (2008) Cryolithogenesis and lithodynamics of the coastal shelf zones of sea in eastern Siberia. Melnikov Permafrost Institute, Yakutsk, p 291 (in Russian)

15. Gosink JP, Baker GC (1990) Salt Fingering in subsea permafrost: some stability and energy considerations. J Geophys Res 95(C6):9575-9583. https://doi.org/10.1029/JC095iC06p09575
16. Grosse G, Schirrmeister L, Kunitsky VV, Hubberten H-W (2005) The use of CORONA images in remote sensing of periglacial geomorphology: an illustration from the NE Siberian coast. Permafrost Periglac 16:163-172. https://doi.org/10.1002/ppp.509

17. Grosse G, Schirrmeister L, Siegert Ch, Kunitsky VV, Slagoda EA, Andreev AA, Dereviagyn AY (2007) Geological and geomorphological evolution of a sedimentary periglacial landscape in Northeast Siberia during the Late Quaternary. Geomorphology 86(1/2):25-51. https://doi.org/10.1016/j.geomorph.2006.08.005

18. Günther F, Overduin PP, Yakshina IA, Opel T, Baranskaya AV, Grigoriev MN (2015) Observing Muostakh disappear: permafrost thaw subsidence and erosion of a ground-ice-rich island in response to arctic summer warming and sea ice reduction. Cryosphere 9:151-178. https://doi.org/10.5194/tc-9-151-2015

19. Harrison WD, Osterkamp TE (1978) Heat and mass transport processes in subsea permafrost 1 . An analysis of molecular diffusion and its consequences. J Geophys Res 83(C9):4707-4712. https://doi.org/10.1029/JC083iC09p04707

20. Hoefs J (1997) Stable isotope geochemistry. Springer, Berlin, p 201

21. Imaeva L, Imaev VC, Koz'min B, Sergeyenko A, Belolyubskii I, Siegert C (2007) Modern structures, quaternary stratigraphy and recent geodynamics in the Arctic sector of the Northern Verkhoyan coastal shelf zone (North of East Yakutia). Bull Comm Stud Quatern Period 67:6-19 (in Russian)

22. Ivanov MS, Katasonova EG (1978) Pecularities of cryolithogenic deposits of the Muostakh Island. In: Anisimova NP, Katasonova EG (eds) Geocryologic and hydrogeologic research in Yakutia. Permafrost Institute, SO AN SSSR, Yakutsk, pp 12-25 (in Russian).

23. Kaplina TN, Lozhkin AV (1979) The age of alas sediments of the Primorskoi lowland of Yakutia (radiocarbon data). Izvestiya USSR Acad Sci Geol Ser 2:69-76 (in Russian)

24. Kholodov AL, Rivkina EM, Gilichinsky DA, Fedorov-Davydov DG, Gubin SV, Sorokovikov VA, Ostroumov VE, Maksimovich SV (2003) Estimation of the organic carbon input into Arctic Ocean due to erosion of Laptev and East-Siberian seashore. Kriosfera Zemli (Earth' Cryosphere) 7:3-12

25. Kholodov AL, Zolotareva BN, Shirshova LT (2006) Organic matter in the main types of frozen quaternary deposits of the Bykovsky Peninslua: total content and group compositon of the humus. Kriosfera Zemli (Earth' Cryosphere) 10:29-34

26. Kholodov A, Gilichinsky D, Ostroumov V, Sorokovikov V, Abramov A, Davydov S, Romanovsky V (2012) Regional and local variability of modern natural changes in permafrost temperature in the Yakutian coastal lowlands, Northeastern Siberia. In: Proceedings of the Tenth international conference on permafrost, Salekhard, Yamal-Nenets Autonomous District, Russia, pp 25-29

27. Kienast F, Schirrmeister L, Siegert C, Tarasov P (2005) Palaeobotanical evidence for warm summers in the East Siberian Arctic during the last cold stage. Quatern Res 63(3):283-300. https://doi. org/10.1016/j.yqres.2005.01.003

28. Kunitsky VV (1989) Kriolitologiya nizo'ev Leny (Cryolithology of the Lower Lena). Permafrost Institute Press, Yakutsk, p 162 (in Russian).

29. Lantuit H, Atkinson D, Grigoriev M, Rachold V, Grosse G, Hubberten H-W (2011) Coastal erosion dynamics on the permafrostdominated Bykovsky Peninsula, North Siberia, 1951-2006. Polar Res 30:7341. https://doi.org/10.3402/polar.v30i0.7341

30. Nagaoka D, Saijo K, Fukuda M (1995) Sedimental environment of the Edoma in high Arctic eastern Siberia. In: Takahashi K, Osawa A, Kanazawa Y (eds) Proceedings of the 3rd symposium on the Joint Siberian Permafrost Studies between Japan and Russia, Hokkaido University, Tsukuba, Japan, pp 8-13

31. Osterkamp TE (2001) Subsea Permafrost. In: Steele JH, Thorpe SA, Turekian KK (eds), Encyclopedia of ocean 
sciences. Academic Press, London, pp 2902-2912. https://doi. org/10.1006/rwos.2001.0008

32. Overduin PP, Wetterich S, Günther F, Grigoriev MN, Grosse G, Schirrmeister L, Hubberten H-W, Makarov A (2016) Coastal dynamics and submarine permafrost in shallow water of the central Laptev Sea, East Siberia. Cryosphere 10:1449-1462. https://doi.org/10.5194/tc-10-1449-2016

33. Overduin PP, Blender F, Bolshiyanov DY, Grigoriev MN, Morgenstern A, Meyer H (2017) Russian-German Cooperation: expeditions to Siberia in 2016, Berichte zur Polar- und Meeresforschung $=$ Reports on polar and marine research, vol 709. Alfred Wegener Institute for Polar and Marine Research, Bremerhaven, p 295

34. Overduin PP, Strzelecki MC, Grigoriev MN, Couture N, Lantuit H, St-Hilaire-Gravel D, Günther F, Wetterich S (2014) Coastal changes in the Arctic. In: Martini IP, Wanless HR (eds) Sedimentary coastal zones from high to low latitudes: similarities and differences, vol 388. Special Publications Geological Society, London. https://doi.org/10.1144/SP388.13

35. Reimer PJ, Bard E, Bayliss A, Beck JW, Blackwell PG, Bronk Ramsey C, Buck CE, Cheng H, Edwards RL, Friedrich M, Grootes PM, Guilderson TP, Haflidason H, Hajdas I, Hatté C, Heaton TJ, Hoffmann DL, Hogg AG, Hughen KA, Kaiser KF, Kromer B, Manning SW, Niu M, Reimer RW, Richards DA, Scott EM, Southon JR, Staff RA, Turney CSM, van der Plicht J (2013) INTCAL13 and MARINE13 radiocarbon age calibration curves 0-50,000 years cal BP. Radiocarbon 55(4):1869-1887

36. Reineck H-E, Sing IB (1980) Depositional sedimentary environments, 2nd rev. Springer, Berlin, p 551

37. Rethemeyer J, Dewald A, Fülöp R, Hajdas I, Höfle S, Patt U, Stapper B, Wacker L (2013) Status report on sample preparation facilities for $14 \mathrm{C}$ analysis at the new CologneAMS centre. Nucl Instrum Methods Phys Res B 294:168-172. https://doi. org/10.1016/j.nimb.2012.04.030

38. Romankevich EA, Vetrov AA, Belyaev NA, Ulyantsev AS, Sergienko VI, Sukhoverkhov SV, Bratskaya SY, Prokuda NA, Semiletov IP (2017) Alkanes in quaternary deposits of the Laptev Sea. Dokl Earth Sci 472(1):36-39. https://doi.org/10.1134/ S1028334X17010093

39. Romanovskii NN, Gavrilov AV, Tumskoy VE, Grigoriev MN, Hubberten H-W, Siegert C (1999) Thermokarst and its role in the formation of the near shore zone of the Laptev Sea shelf. Cryosphere Earth III(3):79-91 (in Russian)

40. Romanovskii NN, Gavrilov AV, Tumskoy VE, Kholodov AL, Siegert C, Hubberten H-W, Sher AV (2000) Environmental evolution in the Laptev Sea region during the Late Pleistocene and Holocene. Polarforschung 67:237-245. https://doi.org/10.2312/ polarforschung.68.237

41. Romanovskii NN, Hubberten H-W, Gavrilov AV, Tumskoy VE, Grigoriev MN, Tipenko GS, Siegert C (2000) Thermokarst and land-ocean interactions, Laptev Sea region, Russia. Permafrost Periglac 11(2):137-152. https://doi.org/10.1002/10991530(200004/06)11:2<137::AID-PPP345>3.0.CO;2-L

42. Romanovsky VE, Drozdov DS, Oberman NG, Malkova GV, Kholodov AL, Marchenko SS, Moskalenko NG, Sergeev DO, Ukraintseva NG, Abramov AA, Gilichinsky DA, Vasiliev AA (2010) Thermal state of permafrost in Russia. Permafrost Periglac 21:136-155. https://doi.org/10.1002/ppp.683

43. Schirrmeister L, Kunitsky VV, Grosse G, Wetterich S, Meyer H, Schwamborn G, Babiy O, Derevyagin AY, Siegert C (2011) Sedimentary characteristics and origin of the Late Pleistocene Ice Complex on North-East Siberian Arctic coastal lowlands and islands-a review. Quatern Int 241:3-25. https://doi. org/10.1016/j.quaint.2010.04.004
44. Schirrmeister L, Oezen D, Geyh A (2002) 230Th/U dating of frozen peat, Bol'shoy Lyakhovsky Island (North Siberia). Quatern Res 57:253-258. https://doi.org/10.1006/qres.2001.2306

45. Schirrmeister L, Siegert C, Kuznetsova T, Kuzmina S, Andreev AA, Kienast F, Meyer H, Bobrov AA (2002) Paleoenvironmental and paleoclimatic records from permafrost deposits in the Arctic region of Northern Siberia. Quatern Int 89:97-118

46. Sergienko AI, Belolyubsky IN, Grinenko OV (2004) Stratigraphic scheme of Quaternary deposits of the northern Verkhoyan (Eastern Yakutia). Otechestvennaya Geol 4:88-92 (in Russian)

47. Shakhova N, Semiletov I, Gustafsson O, Sergienko V, Lobkovsky L, Dudarev O, Tumskoy V, Grigoriev M, Mazurov A, Salyuk A, Ananiev R, Koshurnikov A, Kosmach D, Charkin A, Dmitrevsky N, Karnaukh V, Gunar A, Meluzov A, Chernykh D (2017) Current rates and mechanisms of subsea permafrost degradation in the East Siberian Arctic Shelf. Nat Commun 8:15872. https://doi. org/10.1038/ncomms15872

48. Shakhova N, Semiletov I, Sergienko V, Lobkovsky L, Yusupov V, Salyuk A, Salomatin A, Chernykh D, Kosmach D, Panteleev G, Nicolsky D, Samarkin V, Joye S, Charkin A, Dudarev O, Meluzov A, Gustafsson O (2015) The East Siberian Arctic Shelf: towards further assessment of permafrost-related methane fluxes and role of sea ice. Philos Trans A 373: 20140451. doi.https://doi. org/10.1098/rsta.2014.0451

49. Sher AV, Kuzmina SA, Kuznetsova TV, Sulerzhitsky LD (2005) New insights into the Weichselian environment and climate of the East Siberian Arctic, derived from fossil insects, plants, and mammals. Quatern Sci Rev 24:533-569. https://doi.org/10.1016/j. quascirev.2004.09.007

50. Siegert C, Schirrmeister L, Babiy O (2002) The sedimentological, mineralogical and geochemical composition of late Pleistocene deposits from the ice complex on the Bykovsky peninsula, northern Siberia. Polarforschung 70(2000):3-11. https://doi. org/10.2312/polarforschung.70.3

51. Slagoda EA (1991) Microstructure features of the deposits of Ice Complexes in Northern Yakutia (by the example of Bykov Peninsula). In: Gilichinskiy DA (ed) Kriologiya pochv. IPFS PNTs AN SSSR, Pushchino, pp 38-47 (in Russian)

52. Slagoda EA (1993) Genesis and microstructure of cryolithogenic deposits at the Bykovsky Peninsula and the Muostakh Island. Diss., RAS Sibirian Section. Permafrost Institute, Yakutsk, pp 1-218 (in Russian)

53. Slagoda EA (2004) Cryolithogenic deposits of the Laptev Sea coastal plain: lithology and micromorphology. Publishing and Printing Centre Express, Tyumen, p 119 (in Russian)

54. Strauss J, Schirrmeister L, Grosse G, Wetterich S, Ulrich M, Herzschuh U, Hubberten HW (2013) The deep permafrost carbon pool of the Yedoma region in Siberia and Alaska. Geophys Res Lett 40:6165-6170. https://doi.org/10.1002/2013GL058088

55. Strauss J, Schirrmeister L, Grosse G, Fortier D, Hugelius G, Knoblauch C, Romanovsky V, Schädel C, Schneider von Deimling T, Schuur EAG, Shmelev D, Ulrich M, Veremeeva A (2017) Deep Yedoma permafrost: a synthesis of depositional characteristics and carbon vulnerability. Earth Sci Rev 172:75-86. https://doi. org/10.1016/j.earscirev.2017.07.007

56. Stuiver M, Polach HA (1977) Discussion: reporting of ${ }^{14} \mathrm{C}$ Data. Radiocarbon 19:355-363

57. Tomirdiaro SV, Chernen'k'ii BI (1987) Cryogenic deposits of East Arctic and Sub Arctic. AN SSSR Far-East-Science Center, Magadan, pp 1-196 (in Russian)

58. Ulyantsev AS, Romankevich EA, Bratskaya SYu, Prokuda NA, Sukhoverkhov SV, Semiletov IP, Sergienko VI (2017) Characteristics of the Quaternary sedimentation at the Laptev Sea Shelf based on molecular composition of n-Alkanes. Dokl Earth Sci 473(2):449-453. https://doi.org/10.1134/S1028334X17040158 
59. Ulyantsev AS, Romankevich EA, Bratskaya SYu, Semiletov IP, Avramenko VA (2017) Organic and Inorganic carbon in permafrost and thawed deposits from Buor-Khaya Bay (Laptev Sea). Dokl Earth Sci 473(2):467-471. https://doi.org/10.1134/S1028 $334 X 17040237$

60. Ulyantsev AS, Bratskaya SYu, Romankevich IP, Semiletov EA, Avramenko VA (2016) Particle size composition of HolocenePleistocene deposits of the Laptev Sea (BuorKhaya Bay). Dokl Earth Sci 467(part 1):241-245. https://doi.org/10.1134/S1028 $334 X 16030168$

61. Ulyantsev AS, Romankevich EA, Peresypkin VI, Belyaev NA, Vetrov AA, Semiletov IP, Bratskaya SY, Sergienko VI (2016) Lignin as an indicator of the sedimentation conditions of the Arctic Shelf. Dokl Earth Sci 467(1):264-269. https://doi.org/10.1134/ S1028334X16030089

62. Ulyantsev AS, Polyakova NV, Romankevich EA, Semiletov IP, Sergienko VI (2016) Ionic composition of pore water in shallow shelf deposits of the Laptev Sea. Dokl Earth Sci 467(1):308-313. https://doi.org/10.1134/S1028334X16030211
63. Walter Anthony KM, Zimov SA, Grosse G, Jones MC, Anthony P, Chapin FS III, Finlay JC, Mack MC, Davydov S, Frenzel P, Frolking S (2014) A shift of thermokarst lakes from carbon sources to sinks during the Holocene epoch. Nature 511:452-456. https:// doi.org/10.1038/nature 13560

64. Wenthworth CK (1922) A scale of grade and class terms for clastic sediments. J Geol 30(5):377-392. https://doi.org/10.1086/622910

65. Wetterich S, Overduin PP, Grigoriev MN (2011) Russian-German cooperation SYSTEM LAPTEV SEA: the expedition Eastern Laptev Sea-Buor Khaya Peninsula 2010. Berichte zur Polar- und Meeresforschung/Reports on Polar and Marine Research, vol 629, p 101 (ISSN 1866-3192)

66. Wetterich S, Schirrmeister L, Pietrzeniuk E (2005) Freshwater ostracodes in Quaternary permafrost deposits from the Siberian Arctic. J Paleolimnol 34:363-376. https://doi.org/10.1007/s1093 3-005-5801-y 